\title{
DIVERSIFICATION PRINCIPLES OF REAL ESTATE PORTFOLIOS
}

\author{
Katarzyna Śmietana, PhD \\ Faculty of Investments and Real Estate \\ University of Economics in Katowice \\ e-mail:katarzyna.smietana@ue.katowice.pl
}

\begin{abstract}
Diversifying an investment portfolio through the diversification of assets, which is accompanied by the dispersion of risk, is aimed at achieving an appropriate balance between the expected return and an acceptable level of investment risk. While considering the specificity of various forms of investing in property, the level of the liquidity risk of property assets and the risk of financial instruments in the real estate market, as well as the volume of the capital involved and the regional differentiation of its allocation, this paper intends to present the possible ways of diversifying the portfolio, including sectoral and geographical diversification on the assumption that investments are concentrated in metropolitan areas. The identification of investment portfolio diversification principles, including liquid assets and the real estate market, embraces this perspective on the conditions of the functioning of EU REITs, whose business goal is to manage professionally diversified real estate portfolios.
\end{abstract}

Keywords: investment property, real estate portfolio, diversification.

JEL Classification: G 11, G 31.

Citation: Śmietana K., 2014, Diversification principles of real estate portfolio, Real Estate Management and Valuation, vol. 22, no. 1, pp. 54-60.

DOI: $10.2478 /$ remav-2014-0007.

\section{Introduction}

The important attributes of real estate, namely its profitability and ability to hold value, make it a popular object of capital allocation both for individual investors and especially institutions. The latter want to multiply their capital by including real estate in their investment portfolios, which are diversified and, as such, offer lower risk and satisfactory returns, particularly to conservative investors. Property as a portfolio component is considered to be an investment that creates future income and ensures the appreciation of the value of the invested capital. Its benefits depend on the usage (utility function), provided standard (quality of the building and leased space), and results of the adopted strategy and actions in terms of value management. Seeking to maximize financial gains related to individual assets, the investor looks for the best possible (economically optimal) way in which they can be developed and managed.

In broader terms, direct and indirect property investments ensure capital gains (capital investment property), financial income (debt and equity financial instruments in the real estate market) and benefits (rental investment property), as well as allowing investment risk to be managed through property derivatives (derivative financial instruments in the real estate market).

Reasons presented to institutional investors for including property in their investment portfolios that have been provided in literature on the topic can be divided into traditional and modern. The former include: satisfactory return on the investment (high gross margin profitability of total capital), low price volatility, high returns in relation to risk, potential for protection against inflation and deflation, stable rental revenue components, predictable components of operating expenses, and a low correlation with other assets, which allows for the diversification of the portfolio. An argument put 
forward nowadays is the role of real estate as a significant element of the global investment market (from the portfolio investors' perspective), resulting in the wider use of these particular assets in modern financial instruments (DUCOUlOMBIER 2007). Assuming that the investment portfolio is characterized by a number of investment instruments held by individual (natural persons) or institutional investors, including companies (legal persons), the property market portfolio includes non-financial assets obtained directly (investment property) and indirectly through acquired financial instruments of the real estate market. In principle, it includes non-financial investment instruments and liquid assets, while the diversity of investments applies to the entire portfolio, regardless of its elements.

This paper intends to present a theoretical view on the principles of real estate portfolio diversification by indicating the need for further studies to place more focus on the significance of financial instruments, particularly property derivatives, that in mature markets are regarded as instruments of real estate portfolio risk management.

\section{Real estate diversity as a determinant of portfolio diversification principles}

Diversification is a strategy consisting of the distribution of available resources among different types of investments with respect to financial instruments and including the sectoral diversification of their issuers. The implementation of this strategy is aimed at reducing risk and achieving the expected returns on investment. The principles of diversification are essentially common to financial instruments and property. In relation to the latter, it is defined as the practice of dispersing and spreading capital by investing in property while accounting for its geographical diversity, with investments concentrated in selected geographical regions (usually defined as administrative areas), which is aimed at reducing risk. The observed practice of the dispersion and spread of investment consists of diversifying asset classes and types within various sectors and regions, separated administratively or geographically (HOESLI, LIZIERI 2007).

The overriding objective is reducing the impact of specific risk factors: sectoral and geographical. The real estate market portfolio is described as a selected set of legal rights to property, resulting from undertaken investments that were sectorally and geographically diverse (HOESLI, LEKANDER 2007).

By allocating resources, the investor acknowledges the adopted principles of the investment policy that are subject to the formulated strategy. In the case of professional real estate investors, the principal investment objectives are: the protection of real asset value, achieving investment revenues, and an increase in asset value resulting from the increase in investment value. The investment policy principles determine the means of achieving the investment objective, in particular: the types of securities and other property rights which are the subject of investment, investment selection criteria, investment diversification principles, possible investment restrictions, and the acceptable value of loans taken out by the investor ${ }^{1}$.

The consideration of the real estate portfolio diversification principles includes an aspect related to the liquidity of assets which are the subject of investment. Liquidity should be considered as a multidimensional concept, related not only to the time of withdrawal from an investment, but also to the direct and indirect costs of the transaction, the risk and uncertainty of achieving the expected sales price and the price factors of the sale/purchase agreements, dependent on the nature of the investments and on the market conditions (Kucharska-Stasiak, 2006). The risk of asset liquidity in terms of portfolio diversification is considered as: the cost of the rapid liquidation of a portfolio, uncertainty about the sale with no impact on prices, the cost of an immediate sale, and the protection of capital.

The diversification of investments that acknowledges the diversity of property, including its types, classes and location factors, determines the possible sectoral dispersion of the investment, which is recognized by market analysts as a means of diversification that is of paramount importance (DuCOUlOMBIER 2007). The geographical dispersion of an investment produces results dependent on the property type (CHENG, ROULAC 2007), while the conducted studies distinguish economic regions

\footnotetext{
${ }^{1}$ Ustawa z dnia 27 maja 2004 r. o funduszach inwestycyjnych, Dz.U. 2004, nr 146, poz. 1546 z późn.zm./ The Act on investment funds of 27 May 2004. Official Journal of Laws 2004, No. 146, item. 1546, with subsequent amendments.
} 
which are more significant to diversification than administrative units (DUCOULOMBIER 2007) or metropolitan areas (HOESLI, MACGREGOR 2000) in which the investment capital is concentrated. The diversification of portfolios is also a result of including assets characterized by different investment potentials, including revenue-generating real estate and property with value-adding potential (BACZEWSKI, HANDS, LATHEM 2003; SHILLING, WURTZEBACH 2012).

Taking into account the level of acceptable risk and the expected return that depends on rental revenues and/or the potential increase in the value of the invested capital, and acknowledging the participation of external financing as well as the level of control over the resource, real estate as a portfolio component can be divided according to the typology proposed by the NCREIF 2 into "core" property (strategic rental investment property), "value added" property (development property), and "opportunistic" property (speculative property).

Strategic property is defined as assets providing steady revenue from rent which is an indicator of its overall profitability. This type of property represents the main sectors of the commercial real estate market that institutional investors find the most attractive: office property, retail property, warehouses and logistics centers, residential apartment buildings and hotel facilities. The second type is represented by assets which have a potential for an increase in value, are characterized by average volatility and whose value-added effect largely determines their profitability. These include the main property types as well as nursing homes, hospital facilities, recreational facilities, and dormitories. Speculative property are assets described as alternative (often having the character of special-purpose property), which are the subject of speculative development investments - property held for trading or leasing and land development projects. These assets are characterized by a large variability of the expected value and their overall profitability is determined by the increase in the value of the invested capital (BACZEWSKI, HANDS, LATHEM 2003).

Investment potential is assessed through the expected rate of return on the investment, as indicated by the property index. As regards the proposed classification (BACZEWSKI, HANDS, LATHEM 2003) indicated in Table 1, it is the "NCRIEF Property Index" which constitutes the benchmark in the analysis of investment property and functions as an indicator in the classification of commercial property.

Table 1

Typology of property as a portfolio component according to NCREIF

\begin{tabular}{|c|c|c|c|}
\hline & CORE & VALUE ADDED & OPPORTUNISTIC \\
\hline Expected return & $\begin{array}{l}\text { Stable cash flows, the level of } \\
\text { return commensurate with } \\
\text { the level of risk. } \\
\text { Return reflects the NCREIF } \\
\text { Property Index, } 10-12 \% \text { per } \\
\text { year. }\end{array}$ & $\begin{array}{l}\text { The investment added value } \\
\text { effect is to provide returns of } \\
12-15 \% \text { per year. Returns are } \\
\text { expected to exceed the } \\
\text { NCREIF Property Index by } \\
200 \text { basis points. }\end{array}$ & $\begin{array}{l}\text { Generated profits allow } \\
\text { returns of over } 15 \% \text { to be } \\
\text { achieved in order to } \\
\text { compensate for the high level } \\
\text { of investment risk. Returns } \\
\text { are expected to exceed the } \\
\text { NCREIF Property Index by } \\
500 \text { basis points. }\end{array}$ \\
\hline $\begin{array}{l}\text { Other } \\
\text { investment } \\
\text { characteristics }\end{array}$ & $\begin{array}{l}\text { Property in the institutional } \\
\text { investors sector. Possesses } \\
\text { the expected attributes } \\
\text { (physical attributes, } \\
\text { economic location, } \\
\text { investment scale). Lots } \\
\text { considered attractive in local } \\
\text { and regional markets, high } \\
\text { quality architectural } \\
\text { solutions and construction, } \\
\text { significant occupancy. } \\
\text { High level of control } \\
\text { exercised over the assets. }\end{array}$ & $\begin{array}{l}\text { Investments aimed at } \\
\text { increasing property value, } \\
\text { including development } \\
\text { projects related to the } \\
\text { adaptation to a new } \\
\text { function, remodeling or } \\
\text { expansion, which require } \\
\text { recapitalization. Average } \\
\text { level of control exercised } \\
\text { over the assets. }\end{array}$ & $\begin{array}{l}\text { Niche investments, including } \\
\text { international markets or } \\
\text { capital allocation in property } \\
\text { with a significant untapped } \\
\text { investment potential. Often } \\
\text { require the use of modern } \\
\text { finance solutions. Low level of } \\
\text { exercised asset control. }\end{array}$ \\
\hline $\begin{array}{l}\text { The level of } \\
\text { debt }\end{array}$ & $\begin{array}{l}\text { Low participation of external } \\
\text { financing in the total net } \\
\text { asset value - up to } 30 \% \text {. For }\end{array}$ & $\begin{array}{l}\text { Average level of debt with a } \\
\text { limit of up to } 70 \% \text { of the } \\
\text { value. }\end{array}$ & $\begin{array}{l}\text { High debt which may reach } \\
75 \% \text { or more. }\end{array}$ \\
\hline
\end{tabular}

2 The National Council of Real Estate Investment Fiduciaries. 
basic facilities, a moderate

level of debt with a limit of

$50 \%$ in relation to the

property value.

Phase of the real Operational Operational

estate life cycle

Investment - adaptation in the

development process;

Liquidation - restructuring

(redeveloping)

Source: based on BACZEWSKI, HANDS, LATHEM (2003).

The typology of property as a potential investment asset presented in Table 1 allows the basic characteristics of a diversified real estate portfolio with varying investment potential to be defined. A portfolio with plenty of "core" property and a low LTV ratio allows the investor to expect a relatively high return, characterized by low volatility. A portfolio including a lot of property with a value added potential ("value added" property), but requiring capital injections is characterized by less predictable cash flows. The results of prospective development projects also remain uncertain. The return on this portfolio is largely determined by the appreciation of the capital invested in the asset, and will exhibit average volatility. The portfolio of alternative ("opportunistic") assets offers a chance to achieve above-average returns; however, it is characterized by strong fluctuations in profitability due to the exposure to risky development investments, including speculative ones. One should also emphasize the importance of risk factors resulting from the limited control over assets, as well as from the applied financial engineering and the high level of debt.

In a bid to diversify the assets, certain actions are proposed (DUCOULOMBIER 2007). They have been defined at the subsequent stages of active investment portfolio management and include: defining the objectives and assessing the feasibility of meeting them, choosing strategic objectives the implementation of which is superior and most likely, taking into account obstacles connected with the restructuring of the portfolio and considering any other limitations. Portfolio management activities which are to result in the formulation of a strategy aimed at reducing the investment risk have been presented in Table 2.

Table 2

The stages of active real estate portfolio management

\begin{tabular}{ll}
\hline Objectives & $\begin{array}{l}\text { 1. Selecting a reference portfolio and a reference investment (benchmark) } \\
\text { 2. Defining the expected return in relation to the benchmark } \\
\text { 3. Determining the level of acceptable risk } \\
\text { 4. Determining the time period in which the objectives are to be reached } \\
\text { and determining the way of measuring the results }\end{array}$ \\
\hline $\begin{array}{l}\text { Analysis of the existing } \\
\text { portfolio }\end{array}$ & $\begin{array}{l}\text { Comparison of the existing capital assets with ones forming the benchmark } \\
\text { and analyzing the results achieved so far }\end{array}$ \\
\hline Evaluation of the feasibility of & $\begin{array}{l}\text { Estimation and evaluation of the return on the existing portfolio in relation to } \\
\text { achieving the objectives }\end{array}$ \\
& $\begin{array}{l}\text { the benchmark, and calculating the probability of achieving the investment } \\
\text { goal }\end{array}$ \\
\hline $\begin{array}{l}\text { Identification of barriers } \\
\text { connected with the } \\
\text { restructuring of the portfolio }\end{array}$ & $\begin{array}{l}\text { The need to keep property in a portfolio for which development projects } \\
\text { aimed at increasing the asset value are conducted or anticipated. } \\
\text { The need to take into account the time required to withdraw from the } \\
\text { investment and the costs associated with this process. } \\
\text { Difficulties arising from market conditions. }\end{array}$ \\
\hline Strategy formulation & $\begin{array}{l}\text { New investments. } \\
\text { Property held for sale. } \\
\text { Specific types and locations for real estate designated for takeover. } \\
\text { Identification of needs in terms of operational management }\end{array}$ \\
\hline
\end{tabular}

Source: DUCOULOMBIER (2007, p. 43).

The choice of investments and the degree of their diversification aimed at reducing portfolio risk is subordinated to fixed investment objectives, which in terms of the relevant economic and financial parameters determine the benchmark for investment property. The benchmark is defined as an economic indicator related to property, which can identify a model portfolio or determine the attractiveness of a single investment instrument (a certain property type), and constitutes a certain 
value, a point of reference and a target parameter (or a set of parameters) expected by the investor. A benchmark for a specific property type is determined through values, including technical, functional, behavioral, organizational and economic (FORYś 2006), which determine the operational and market standard ${ }^{3}$, and in the case of investment property are a determinant of its investment attractiveness.

\section{Investment diversification on the example of EU REITs}

The high capital intensity of real estate, significant costs of market monitoring and management, and costs of acquiring information as well as those associated with transactions make diversification as presented in this paper possible in the case of collective investment institutions - real estate companies and investment funds, whose existence reduces the market access barrier (HOESLI, LISIERI 2007) and increases the range of investments characterized by smaller liquidity risk. In the European property market, the role of a professional investor whose primary business goal is to build and manage a geographically and sectorally diversified investment portfolio is played by the EU-REIT structure. Its characteristics have been described in "The EU REIT and the Internal Market for Real Estate" report (EICHHOLTZ, KOK 2007). Taking into account the EU regulations in force, an EU-REIT has the status of a public company listed on the stock exchange, the value of which is related to the actual valuation of property that constitutes its primary portion of assets (Mazurczak, 2011). The company is established with a view of effectively managing the portfolio and rental investment property, the proceeds from which are a vital source of revenue received by the company. Capital gains resulting from purchases and sales occur only in connection with the restructuring of the investment portfolio and are not a result of speculative investments.

Table 3

The status and the main investment objectives of REITs in Europe

\begin{tabular}{|c|c|c|c|}
\hline & $\begin{array}{l}\text { Germany } \\
\text { G-REIT }\end{array}$ & $\begin{array}{l}\text { France } \\
\text { SIIC }\end{array}$ & $\begin{array}{l}\text { United Kingdom } \\
\text { UK-REIT }\end{array}$ \\
\hline Legal form & $\begin{array}{l}\text { The German REIT Act } \\
\text { ("REITA"). } \\
\text { Introduced in } 2007 . \\
\text { A joint-stock company. } \\
\text { Listed in the EU, based in } \\
\text { Germany. }\end{array}$ & $\begin{array}{l}\text { "Sociétés d'Investissements } \\
\text { Immobiliers Cotées." } \\
\text { Introduced in } 2003 . \\
\text { A joint-stock company listed } \\
\text { in France. } \\
\text { Share capital of at least } \\
\text { EUR15 million. }\end{array}$ & $\begin{array}{l}\text { UK REIT. Capital Group. } \\
\text { Introduced in } 2007 . \\
\text { The parent company must be } \\
\text { a UK tax resident. Listed on } \\
\text { the list of global stock } \\
\text { exchanges recognized by the } \\
\text { UK tax authorities. }\end{array}$ \\
\hline $\begin{array}{l}\text { Investment } \\
\text { policies }\end{array}$ & $\begin{array}{l}\text { At least } 75 \% \text { of the assets } \\
\text { derive from direct investments } \\
\text { in real estate. } \\
\text { At least } 75 \% \text { of gross income } \\
\text { derives from rent. } \\
\text { Real estate transactions are not } \\
\text { permitted. }\end{array}$ & $\begin{array}{l}\text { Property located exclusively } \\
\text { in France. }\end{array}$ & $\begin{array}{l}\text { At least } 75 \% \text { of the assets } \\
\text { derive from direct } \\
\text { investments in the real estate } \\
\text { rental business. At least } 75 \% \\
\text { of income from rents in } \\
\text { operational income. } \\
\text { Minimum } 3 \text { types of assets in } \\
\text { the portfolio. } \\
\text { Permissible international } \\
\text { diversification and real estate } \\
\text { development activities } \\
\text { (limited). }\end{array}$ \\
\hline Debt limits & $\begin{array}{l}55 \% \text { of the value of real estate } \\
\text { assets }\end{array}$ & None & $\begin{array}{l}\text { Regulated by the ratio } \\
\text { (Finance Cost Ratio) of } 1.25 \text {. } \\
\text { REIT earnings should be at } \\
\text { least } 1.25 \text { times greater than } \\
\text { the cost of financing. }\end{array}$ \\
\hline
\end{tabular}

Source: based on Compare and contrast: Worldwide Real Estate Investment Trust (REIT), Regimes, Report PwC, July 2011.

\footnotetext{
${ }^{3}$ The benchmark determined by parameters defining the market standard for property as a portfolio component includes: the gross/net capitalization rate, current and effective profitability of the property, market transaction prices, rental rates, operating expenses and vacancy rates.
} 
A REIT has a privileged tax status, provided that the assumed dividend policy is implemented (EICHHOLTZ, KOK 2007). The selected characteristics of REIT structures in selected countries, i.e., Germany, France and Great Britain, have been shown in Table 3.

European real estate companies making investments within the determined investment policy objectives apply the principles of geographical and sectoral diversification, and that in which different property types are taken into account. The presented research results (EICHHOLTZ, KOK 2007) on real estate companies with market capitalization exceeding EUR50 million confirm the applied geographical diversification (including international diversification), and it is assumed that national companies concentrate more than $75 \%$ of the total investment in the country of origin. Out of 124 examined real estate companies, $90(77.2 \%)$ operate in domestic markets, while $34(22.8 \%)$ in international ones. The sectoral diversification disclosed by analysts corresponds to the concentration of investments in one sector - 33 companies (26.6\%), two sectors - 48 companies (38.7\%), three sectors $37(29.8 \%)$, and four or more sectors - 6 companies $(4.8 \%)$, with a minimum investment of $10 \%$ of assets in a specific sector. The dispersion of investments in various property types is practiced by most companies with the same assumption. The majority of companies (71\%) invest in office property, retail property $-57.3 \%$, warehouses $-29 \%$, residential housing $-20.2 \%$, hotels $-5.6 \%$, and other property types - 30.6\% (EICHHOLTZ, KOK 2007).

\section{Conclusions}

The study of relevant literature has allowed conclusions regarding the applied diversification principles of a real estate portfolio in relation to professional investors of an EU-REIT status to be drawn:

- Sectoral and geographical diversification in the national property market;

- Sectoral diversification including investments in the global market;

- Geographical diversification with acknowledgement of geographical, administrative and economic regions;

- Diversification in terms of the scale of the investment (defined in relation to quality - physical characteristics, or quantity - property value) and the nature of the investment (metropolitan, location in metropolitan areas $\left.{ }^{4}\right)$;

- Diversification in terms of property investment potential and the means of capital recovery by the investor;

- Diversification in relation to asset liquidity risk.

Changing market conditions require a dynamic approach to the management of investments in real estate, which is reflected by spreading and dispersion in order to reduce the negative impact of risk factors in face of dynamic changes in the environment. Managing a diversified real estate portfolio is aimed at creating value, mostly as a result of the selection of investments and strategic assets, and the management of directly controlled property; this is subordinated to the realization of the investment policy principles and the target effect in the form of the expected return and accepted level of investment risk. An EU-REIT is a structure which holds the potential to achieve these objectives - namely, sector and geographical diversification, recognizing the significance of crossborder investments that enable investment diversification.

The use of financial instruments, including property derivatives, as a means of diversification is bound to increase the scope of the instruments used to date.

\section{References}

BACZEWSKI J., HANDS K., LATHEM Ch. R., 2003, Real Estate Investment Styles, REPORT, NATIONAL

COUNCIL OF REAL ESTATE INVESTMENT FIDUCIARIES, http:/ / www.ncreif.org/resources.aspx,

CHENG, P., ROULAC S., 2007, Measuring the effectiveness of geographical diversification, JOURNAL OF REAL Estate PortFolio MANAGEMENT, VOL. 13, No 1,

Ducoulombier F., 2007, I'Investissement et la Gestion du Risque Immobiliers en Europe, PUblication DE

\footnotetext{
4 A metropolitan area is a highly-urbanized area with the prevalence of metropolitan functions of potential development opportunities. From: T. Markowski, T. Marszał: Metropolie, obszary metropolitalne, metropolizacja - Problemy i pojęcia podstawowe. Komitet Przestrzennego Zagospodarowania Kraju PAN, Warsaw, 2006, pp. 15, 17.
} 
L'EDHEC RISK AND ASSET MANAGEMENT RESEARCH CENTRE, web : www.edhec-risk.com,

EICHHOLTZ P., KOK N., 2007, The EU REIT and the Internal Market for Real Estate, Report for the European Landowners Organization, the European Property Federation, the Royal Institution of Chartered Surveyors, The European Group of Valuers' Associations, and the Urban Land Institute Europe.

HoEsli M. E., LeKANDER J., 2007, Real Estate Portfolio Strategy and Product Innovation in Europe. Report. Universite de Geneve, http:/ / archive-ouverte.unige.ch/unige:5736.

Hoesli M. E., MacGregor B.D., 2000, Property investment: Principles and practice of portfolio management, Pearson Education, Edinburgh.

Hoesli M., Lizieri C., 2007, Real estate in the investment portfolio. REPORT, Report to the Investment Strategy Council of the Norwegian Ministry of Finance, http://centaur.reading.ac.uk/view/creators/90002838.html

KUCHARSKA-STASIAK E., 2006, Nieruchomość w gospodarce rynkowej. Wydawnictwo Naukowe PWN, Warszawa.

MARKOWSKI T., MARSZAŁ T., 2006, Metropolie, obszary metropolitarne, metropolizacja - Problemy i pojęcia podstawowe. Komitet Przestrzennego Zagospodarowania Kraju PAN, Warszawa.

MAZURCZAK A., 2011, Znaczenie funduszy nieruchomości typu real estate investment trust (REIT) w rozwoju rynku nieruchomości w Polsce, Rozprawa doktorska, Uniwersytet Ekonomiczny, Poznań.

SHILLING J.D., WURTZEBACH CH.H., 2012, Is value-added and opportunistic real estate investing beneficial? If so, why? Journal of Real Estate, Research, Vol. 34, No 4.

Zarządzanie nieruchomościami komercyjnymi, 2006, red. nauk. I. Foryś, Poltext, Warszawa.

Compare and contrast, Worldwide Real Estate Investment Trust (REIT). Regimes, 2011, REPORT, PWC, http://www.pwc.co.uk/real-estate/publications/worldwide-real-estate-investment-trustregimes.jhtml.

Ustawa z dnia 27 maja 2004 r. o funduszach inwestycyjnych, Dz. U. 2004, nr 146, poz. 1546 z późn.zm./ The Act on investment funds of 27 May 2004. Official Journal of Laws 2004, No. 146, item. 1546, with subsequent amendments. 